International Journal of Applied Chemistry.

ISSN 0973-1792 Volume 11, Number 4 (2015) pp. 427-441

(C) Research India Publications

http://www.ripublication.com

\title{
Sponge Role In Alleviating Oil Pollution Through Sludge Reduction, A Preliminary Approach
}

\author{
Ismail Marzuki ${ }^{1}$, Alfian Noor ${ }^{1}$, Nursiah La Nafie ${ }^{2 *}$, and M. NatsirDjide ${ }^{3}$ \\ ${ }^{1}$ Radiation Chemistry Laboratory, ${ }^{2}$ Analytical Chemistry Laboratory, and \\ ${ }^{3}$ Pharmaceutical Microbiology Laboratory, Hasanuddin University \\ Kampus UNHAS Tamalanrea, Makassar, Indonesia 90245 \\ Contact: *lanafie@lycos.com: Telp./Fax : +062811449024/+062411586498
}

\begin{abstract}
So far very few investigations have been conducted using sponges in converting hydrocarbon components from sludge into simpler compounds. In the meantime, sponges have been recognized as complex animals having various functions including to produce bioactive compounds that areable to interact with oil components. Experiments conducted cover sludge identification, sponge characterization particularly microsymbionts, and after colonization and suspension, mixed with sludge for 35 days under certain treatments, namely: (1) NPK addition, (2) NPK and shaking, (3) shaking only, and (4)untreatment. Each 5 days, mixture was then sampled to measure its visual observation, $\mathrm{pH}$, quantitative analysis of biodegradation rates, and quantitative analysis by GC-MS. Results showed that sponge found was Callyspongia $s p$. and its microsymbiont was BacillusFlexus (BF)strain PHCDB20. Apparently treatment 2 gave the best result in terms of GC-MS analysis. Seemingly oil components like hydrocarbons nC10- nC30 as well as 2,7-dimethyl naphthalene and azulene underwenta sufficiently strong degradation. It can be concluded that Callyspongia sp were able to reduce some hydrocarbon components in sludge samples, either aliphatic or aromatic compounds.
\end{abstract}

Key words: Sludge, hydrocarbons, microsymbiont, sponge, biodegradation rates, GC-MS.

\section{Introduction}

Marinebiota and microorganisms play important roles in the biological processes and material cycles in the marine environment, withno exception to sponges and symbiont microorgamisms. ${ }^{[1]}$ Hydrocarbon components contained oil spillages in the marine 
environment poses a serious threat to marine life because they are toxic, carcinogenic and mutagenic. ${ }^{[2]}$ The potential contamination of petroleum slugde can occur in nearly all lines of petroleum activities ranging from exploration through refining process and potentially waste produced in the form of oil sludges. ${ }^{[3]}$ The main component of petroleum sludge contaminants are aliphatic and aromatic hydrocarbon compounds are hydrophobic, easily attached to organic materials to form solid particles micro pollutant persistent in the environment. ${ }^{[2,4]}$

Slugde petroleum contamination have been managedphysically, chemically and biologysustainably, but less efficient. Hence, contamination prevention study have recentlyshifted to the use of microorganisms that can reduce toxichydrocarbon compounds into simpler compounds withreduced toxicity. ${ }^{[5,6]}$

Biodegradation process requires the existence of microbial activity which is an organism that can potentially be used to degrade petroleum waste. Marine bacteria are capable todegradetoxichydrocarbon components into simple components by utilizing carbon compounds as an energy source ${ }^{[5,7]}$ Biodegradation of hydrocarbons by microbial communities depend on community composition and adaptive response of microorganisms to the presence of pollutants like hydrocarbon material. ${ }^{[3,5]}$ The rate and mechanism of different aliphatic hydrocarbon biodegradation rates and mechanisms of biodegradation of aromatic, aliphatic compounds constituent due to oil generally has a long carbon chain and a heavy fraction, while aromatic hydrocarbons are persistent toxic to biota and marine microorganisms. Yet, some studies show that at optimum conditionthe degradation of the optimum conditions complex compounds aliphatic and aromatic hydrocarbons can be run with varying speed. ${ }^{[2,8,9]}$

Components of petroleum hydrocarbonisa carbon source for growth of microorganisms, so that these components can be degraded properly. The type of hydrocarbon bacteria degrading is Enterobacter sp., Bacillus sp., Clostridium sp., Pseudomonas sp.,Aeromonas spand Citrobacter sp. ${ }^{[10,11]}$ The bacteria can be act as asymbiontwith sponges. ${ }^{[3,12]}$ Bacterial symbionts with a sponge form biomass in the form of spicules and debris. ${ }^{[4,13]}$

Sponges are multicellular metazoan animals, which are porous andfilter feeders, so they can act ashabitats for microorganisms to nest inside the sponge body. Symbiont microorganisms with a sponge has a role in spongesbiological systems, which is both a source of food by microorganisms or by sponge, and microsymbiont make sponge as host for life and utilize micro sponge symbionts in defense in order to adapt and live in polluted environments. ${ }^{[3,5,14,15]}$

Alkane fraction is one of the oil component easily degraded by bacteria than aromatic fraction, or fraction asfaltic and other fractions as alkanes are more soluble in water and diffuses into the cell membranes of bacteria. There are three main factors that determine the rate and mechanism of hydrocarbon biodegradation by microorganisms components, namely: 1) components of hydrocarbons as substrate, including the type, concentration and toxicity, 2) degrading microorganisms, including the type, the number of colonies, nutrients, time, and adaptability, 3) environment, consisting of temperature, $\mathrm{pH}$, pressure, oxygen supply, salinity. ${ }^{[2,3,15]}$

Melawai beach Balikpapan, is one of the beaches with extreme environment for marine life including sponges because it iscontaminated by toxicpetroleum 
pollutants,one cannot expected to findbiota like sponges, but in fact there are at least four specieshave beenidentified, namely (1) Callyspongia $s p$ and (2) Callyspongia vaginalis from class of Callyspongiidae, and (3) Coelocarteiasingaporensis and (4) Haliclona oculata from class of Chalinidae. ${ }^{[13,16,17]}$ The findings led to the understanding that sponges and their mycrosymbiontscan adapt to extreme environments i.e.,contaminated with petroleum hydrocarbon spills.

\section{Materials and Methods}

Materials: Bacillus Flexus (BF) PHCDB20 strain, i.e., microsymbiont Callyspongia $s p$, obtained from areas contaminated with petroleum waste Coast Melawai, Balikpapan, East Kalimantan, Indonesia $\left(01^{0} 16.366^{\prime} 8^{\prime S L}\right.$ and $\left.116^{0} 48.23^{\prime} 6^{\prime \prime} \mathrm{EL}\right)$, temperature $29{ }^{\circ} \mathrm{C}, 30 \%$ salinity, $\mathrm{pH} 7$, and a depth of $2.7 \mathrm{~m},{ }^{[1.17]}$ sludge wasobtained from the processing of the storage tank B number 05, PT. Chevron Pacific, DumaiRiau, Indonesia.

Stages of preparation microsymbiont sponge BF strain PHCDB20, starting with the determination of the sponge species Callyspongia $s p$ through histomorphology analysis, isolation, identification,Gram staining test and biochemical test isolates sponges. ${ }^{[12,15,17]}$ These steps then followed by the determination of species of sponges Callyspongia $s p$ microsymbiont through characterization molecules gene of $16 \mathrm{~S}$ rRNA at PCR method, obtained BF strain PHCDB20. ${ }^{[7,18,19]}$

Experiment: degradation process was conducted by preparing 32 sterile vials (40 $\mathrm{mL}$ ).Each vial filled with15 $\mathrm{mL}$ suspension BF strain PHCDB20 and added $\pm 1 \mathrm{~g}$ sample of sludge to create a contact between the strain and sludges. Vials were divided into four treatment groups, each consisting of 8 pieces of vials. Group (1), plus $5 \mathrm{~mL}$ NPK (5 g/100 mL aquabidesh), group (2) plus $5 \mathrm{~mL}$ of NPK and shake, group (3) in the shaker, and the group (4) without treatment. Every 5 days of contact time samplewas taken fromeach treatment, then suspension and the rest of the sludge is separated through a separating funnel, suspension absorbance was measured at $\lambda 600$ $\mathrm{nm}$, while the remainder of non-degraded sludge was dissolved in $10 \mathrm{~mL}$ dichloromethane GR, shaken until all the sludge dissolved, and settled. ${ }^{\lceil 2,3,5,12]}$

Analysis of hydrocarbon components the sludge is done by taking $50 \mathrm{~mL}$ of dissolved sludge dichloromethane, then diluted with dichlromethane and sprayed with $\mathrm{N}_{2}$ gas to remove water content, samples then were to beready analyzed by GC-MS. Determining the level of biodegradation is done by evaporating thesludge that has been reconstituted with dichloromethane GR until all the solvent disappear, then weighed using the analytical balance Mettler AE-100.

Note: All treatments take place at room temperature $\left(32{ }^{\circ} \mathrm{C}\right)$, density of the suspension measured by spektronic $20 \mathrm{D}^{+}, \lambda 600 \mathrm{~nm}$, shake with a speed of $100 \mathrm{rpm}$, the composition of NPK; $\mathrm{N}: 25 \%, \mathrm{P}_{2} \mathrm{O}_{5}: 12 \%$, and $\mathrm{K}_{2} \mathrm{O}: 12 \%$.

Contact between the suspension BF strain PHCDB20and sludge lasted for 35 days, with eight series of sampling (starting from 0 days, 5 days, 10 days to 35 days). Parameters measured were; 1 ) visual observation of the degradation process consists of odor and gas, 2) $\mathrm{pH}$ suspension, 3) optical density (OD), 4) the concentration of hydrocarbon components of petroleum sludge before and after degradation. ${ }^{[3,12,16]}$ The 
concentration of hydrocarbons in sludge was determined by using internal standard method.

\section{Results and Discussion}

The characteristics of sludge sample used werechemical sludge which constitute result of chemical coagulation and flocculation, black, semi-solid embodiments, water content: $4.4769 \%$, insoluble materials: $0.7847 \%$, aliphatic compounds: $85.98 \%$, aromatic compounds: $3.03 \%$, and other compounds: $10.99 \%$.

Gases and odors arising during contact between the suspension BF strain PHCBD20 and sludge (BFS) is one indicator of biodegradation(Table 1). ${ }^{[2,3]}$

Table 1. Visual observation of the suspension BF strain PHCBD20 and sludge (BFS) during the process of sludge biodegradation

\begin{tabular}{|l|c|c|c|c|}
\hline Contact time & \multicolumn{4}{|c|}{ Treatments } \\
\hline (days) & 1 & 2 & 3 & 4 \\
\hline 0 & 0 & 0 & 0 & 0 \\
\cline { 2 - 5 } & 0 & 0 & 0 & 0 \\
\hline 5 & 0 & 0 & 0 & 0 \\
\cline { 2 - 5 } & 0 & 0 & 0 & 0 \\
\hline \multirow{3}{*}{10} & 0 & 1 & 0 & 0 \\
\cline { 2 - 5 } & 0 & 0 & 0 & 0 \\
\hline 15 & 1 & 1 & 1 & 0 \\
\cline { 2 - 5 } & 0 & 2 & 0 & 0 \\
\hline \multirow{3}{*}{20} & 1 & 1 & 1 & 1 \\
\cline { 2 - 5 } & 2 & 2 & 2 & 0 \\
\hline 25 & 1 & 1 & 1 & 1 \\
\cline { 2 - 5 } & 2 & 2 & 2 & 2 \\
\hline \multirow{3}{*}{30} & 1 & 1 & 1 & 1 \\
\cline { 2 - 5 } & 2 & 2 & 2 & 2 \\
\hline 35 & 1 & 1 & 1 & 1 \\
\cline { 2 - 5 } & 2 & 2 & 2 & 2 \\
\hline
\end{tabular}

Explanation: $0=$ no odor and gas; $1=$ incurred gas; $2=$ odor

Table 1 shows that in treatment 2, there were gas and odor, in day 10 and 15, respectively,treatments 1 and 3, the identified gas at day 15 and the smell identificationat day 20, while the fourth treatment, gas detected at day 20 and odors on day 25 to contact.

Another indicator shownthat the biodegradation of the sludge occurs due tochanges in $\mathrm{pH}$ of the suspension during the contact process, is clearly shown in Table 2. 
Table 2. The connection between suspension BF strain PHCDB20with a pH during ongoing process biodegradation sludge

\begin{tabular}{|c|c|c|c|c|c|c|c|c|}
\hline \multirow{2}{*}{ Treatment } & \multicolumn{7}{|c|}{ Contact time (days) } \\
\cline { 2 - 9 } & 0 & 5 & 10 & 15 & 20 & 25 & 30 & 35 \\
\hline 1 & 7 & 7 & 7 & 6 & 6 & 6 & 7 & 7 \\
\hline 2 & 7 & 7 & 7 & 6 & 6 & 6 & 6 & 7 \\
\hline 3 & 7 & 7 & 7 & 7 & 7 & 7 & 7 & 7 \\
\hline 4 & 7 & 7 & 7 & 7 & 7 & 7 & 7 & 7 \\
\hline
\end{tabular}

Changes in $\mathrm{pH}$ of the suspension occurs in treatment 1: $\mathrm{pH} 7$ to 6 on the day to $15-25$, and treatment 2: $\mathrm{pH} 7$ to 6 on the day to 15-30, the range of timeof decrease in pHfor treatment 2 is longer than treatment 1 due to the availability of nutrients contained NPK and supply of oxygen, while the treatments 3 and 4 do not change the $\mathrm{pH}$. Change in suspension $\mathrm{pH}$ associated with the growth of bacteria. Increased acidity of the suspension indicates that an increase in the number and size of cell colonies occur in phase 2(the bacterial growth phase). In this phase, the number of bacterial colonies grew and enlarged their cells sizes which results in an increased acidity suspension as a result of the increase in the number of colonies and the growing size of bacterial cells, so that in this phase is estimated to occur a maximum biodegradation. This situation continued until the phase 3 of bacterial growth, the phase where the number of colony growth and increased cell size is the same as the number of bacterial colonies reduction due to death. ${ }^{[3,11,13,21]}$ Treatment 3 and 4 remained an increase in cell size and increase the number of cells, but not optimal because it does not available supply of nutrients and oxygen needed by bacteria to grow, so does not cause a significant change in the $\mathrm{pH}$ of the suspension. This allows the impact on the biodegradation takes place not optimal. ${ }^{[2,21,22]}$

The optical density (OD) suspension can show whether the maximum biodegradation process takes place or not. Suspension absorbance change is one of the parameters which indicate the occurrence of biodegradation of the sludge, whensuspension absorbance value increases, indicating the number of colonies increased and enlarged cell size and an increase in absorbance is also caused due to some of the products of biodegradation in the suspension. ${ }^{[5,12,16]}$ Absorbent suspension is more clearly shown in Figure 1.

Figure 1 shows the optimum absorption occurs for treatment 2 on 25 days to contact (absorbance: 0.61 ) and decreased on day 30 and to day 35 contact but biodegradation persist in low intensity, while the optimum absorption for treatment 1,3 and 4 occurred on days 20 to contactand decreased on day contacts 25-35. 


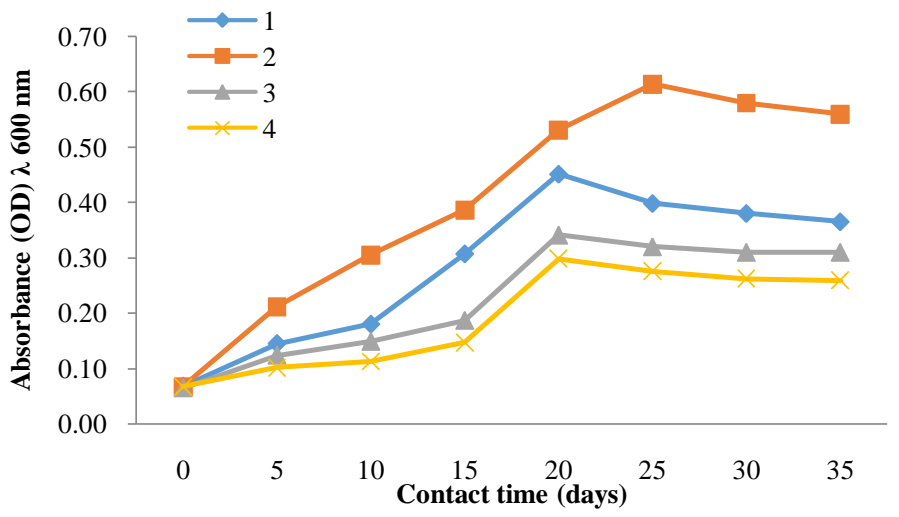

Figure 1. The relationship between absorbance (OD) with contact time to suspension BF strain PHCDB20 versus sludge, $\lambda_{\max .}=600 \mathrm{~nm}$

The difference between the treatment of bacterial optimum point 2 and the treatment 1,3 , and 4, due to the growth period BF strain PHCBD20 are at different stationary phases due to adequate supply of nutrients and oxygen for the treatment 2 , so that the bacteria can grow up to both the number and size of cells sludge is expected to degrade more leverage, whereas in the treatment lof bacterial suspensions shows a lack of oxygen, and treatment 3 andtreatment4indicate lack of nutrients, thus the maximum biodegradation is expected to occur in the treatment 2 compared to other treatments. There are two factors that contribute to the increase in the value of absorbance suspension, namely first: an increase in the number of colonies and increasing cell size BF strainPHCDB20, and second: sludge biodegradation products are partially fused with suspension. ${ }^{[3,5,12,16,23]}$ Correspondence between the absorbance of the suspension at the rate of biodegradation can clearly be seen in Figure 2.

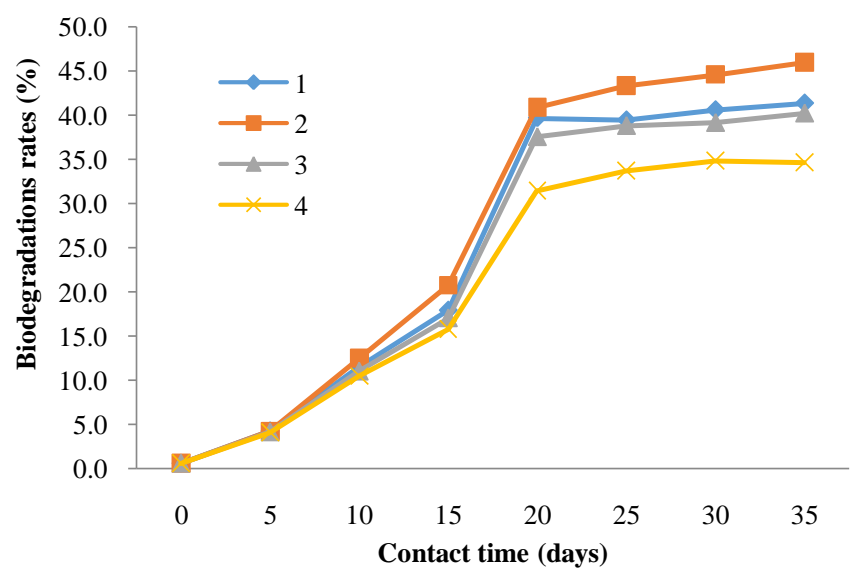

Figure 2.The relationship between biodegradation rates with contact time to suspension BF strain PHCDB20 and sludge 
The maximum biodegradation rate of the order of the treatment 2: (45.93\%), treatment 1: (41.34\%), treatment 3: (40.19\%), and treatment 4: (34.67\%). Treatment 2 dominant biodegradation rate than other treatments began to appear in the contact days to 10 days until their optimum contact to 25 . At the time of the contact of bacteria in a growth phase after a period of adaptation in contact day to $0-10$. Work bacteria in degrading sludge still visible contact took place on the day to 30-35, but less than the maximum because the bacteria at that time already on death phase, the time when the number of colonies and the cell size is reduced until finally all coloniesdie. ${ }^{[12,16,24,25]}$

Figure 2 shows that the biodegradation process takes place in all treatments although its magnitude is different between treatments but estimated to have an impact on changes of the concentration of hydrocarbon components in the sludge by variation of contact time. Changes in the concentration of components in the sludge are shown in Figure 3.

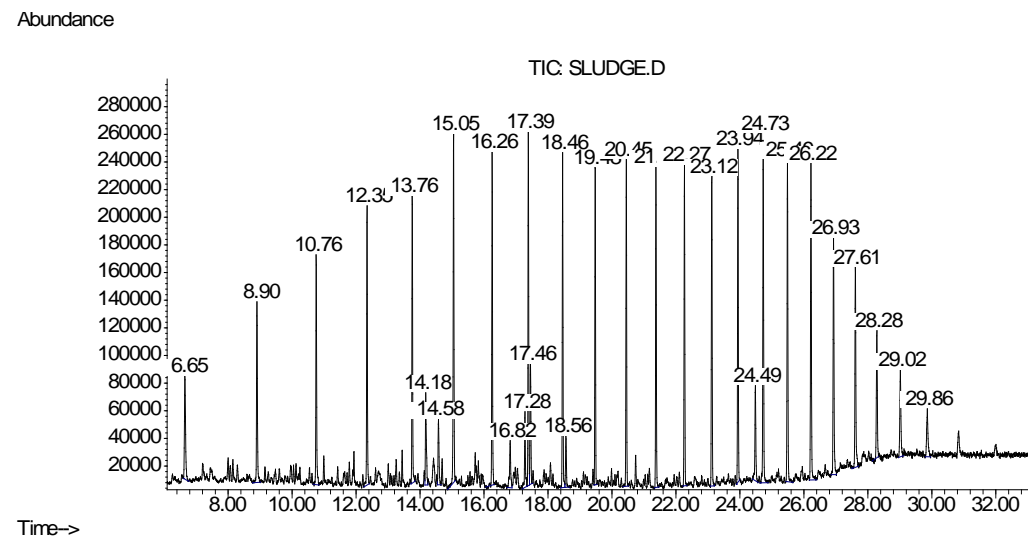

Figure 3a. GC chromatogram of sludge TPH concentrations without treatment
before contact with suspension BF strain PHCDB20 as control (0).

Figure $3 \mathrm{a}$ is sludge chromatogram shows the retention time of each component of sludge with a relative abundance of each measured before any contact between the suspension BF strain PHCDB20 with sludge and also without treatment. The chromatograms compared to the chromatograms after contact with different treatments, hereinafter referred to as the control (0).

Based on the chromatogram (Figure 3a), there are 23 peaks identified that showed hydrocarbon components making up the sludge with the quality of the relative proximity of molecules reach above $93 \%$, they are 21 normal chain alkanes(nC10nC30) and 2 aromatic compounds(2,7 dimethyl napthalene and azulene), and 11 other hydrocarbon components peaks. 
Abundance

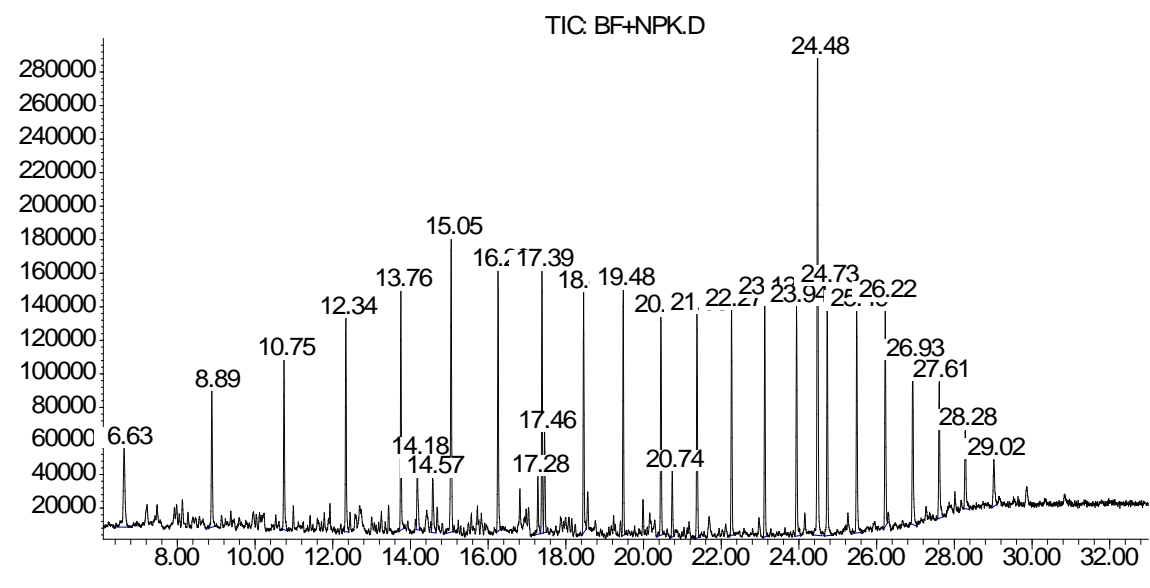

Figure 3b. GC chromatogram of sludge TPH concentrations treatment 1 after contact of 35 days with suspension BF strain PHCDB20.

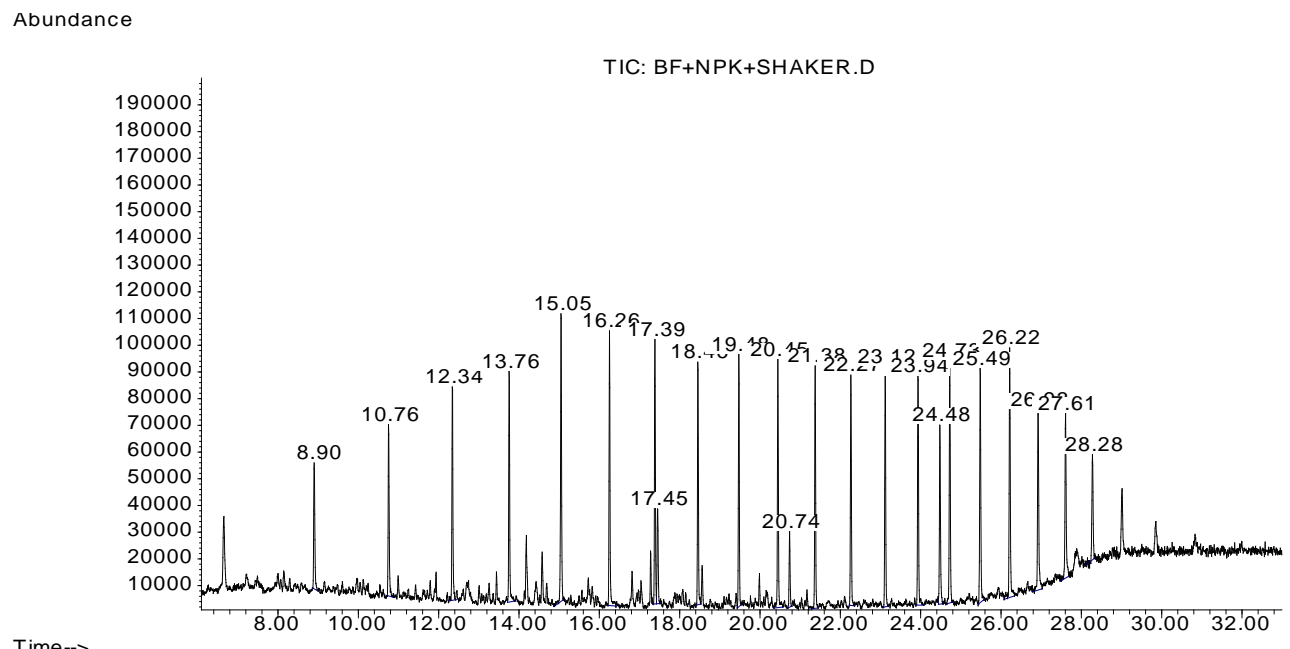

Figure 3c. GC Chromatogram of sludge TPH concentrations treatment 2 after contact of 35 days to suspension BF strain PHCDB20 with sludge.

The GC chromatogram analysis based on retention time and relative abundance of hydrocarbon components showed changes on all treatments compared to the relative abundance of hydrocarbons prior to the contact between the suspension BF strain PHCDB20 with sludge. Significant changes in relative abundance was highest in treatment 2(figure $3 \mathrm{c}$ ) followed by treatment 1 (figure $3 \mathrm{~b}$ ), treatment 3 (figure $3 \mathrm{~d}$ ) and treatment 4 (figure 3e). It is assumed that if there is a decrease in relative abundance, then the component concentrations also decreased and vice versa for retention time and the same hydrocarbon component. ${ }^{[5,12,16,26]}$ 
Abundance

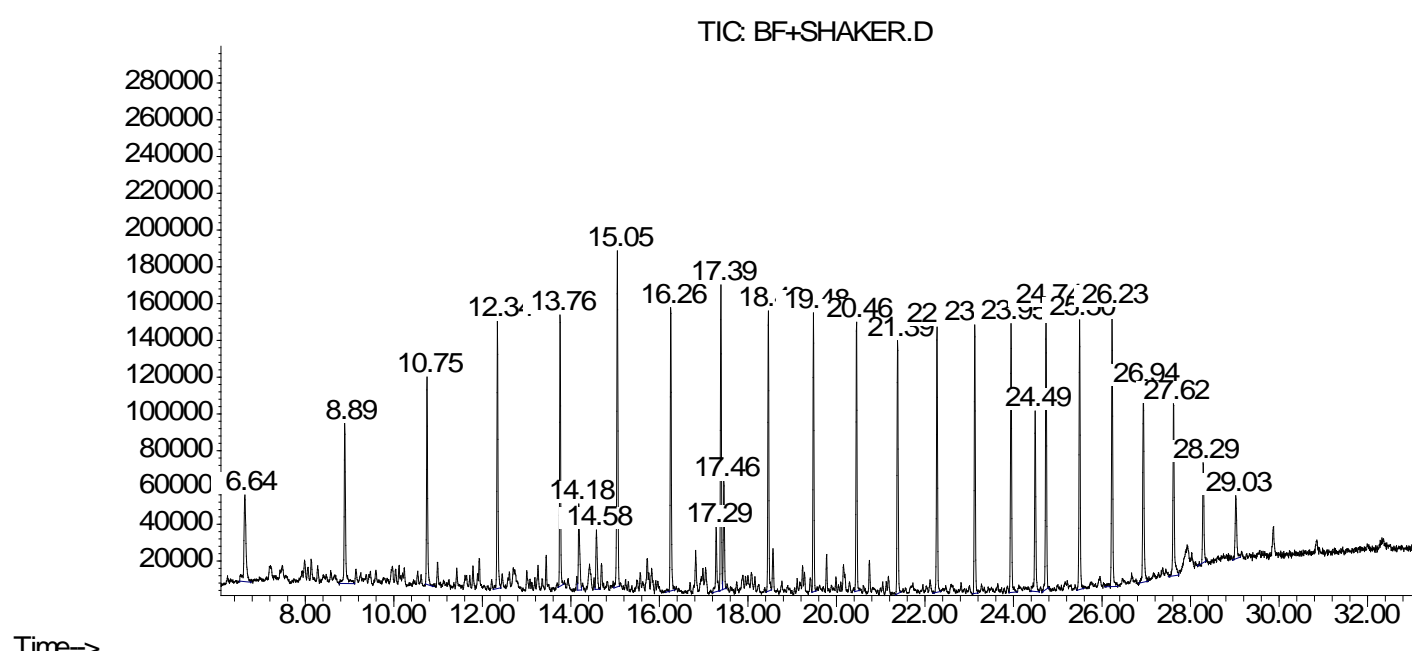

Figure 3d. GC chromatogram of sludge TPH concentrations treatment 3 after contact of 35 days with suspension BF strain PHCDB20.

Abundance

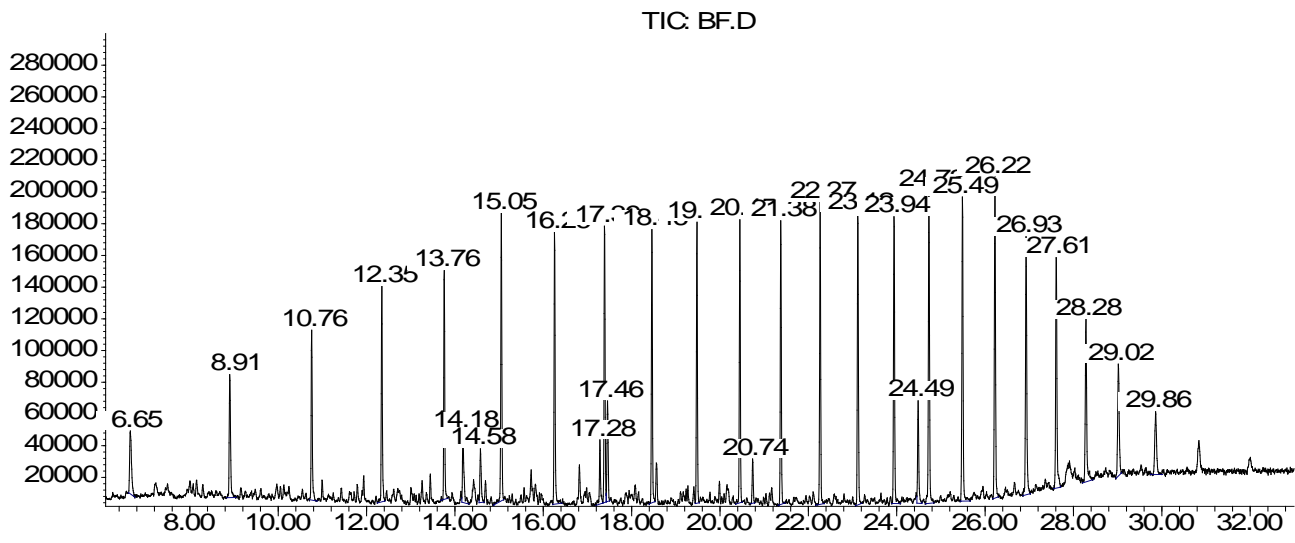

Time $->$

Figure 3e. GC chromatogram of sludge TPH concentrations treatment 4 after contact of 35 days with suspension BF strain PHCDB20.

Results of GC/MS data analysis and calculation of changes in the concentration of hydrocarbons contained in the sludge is based on the assumption of a difference relative abundance for each compound with the same retention time can be seen in Figures 4, 5, and 6. 


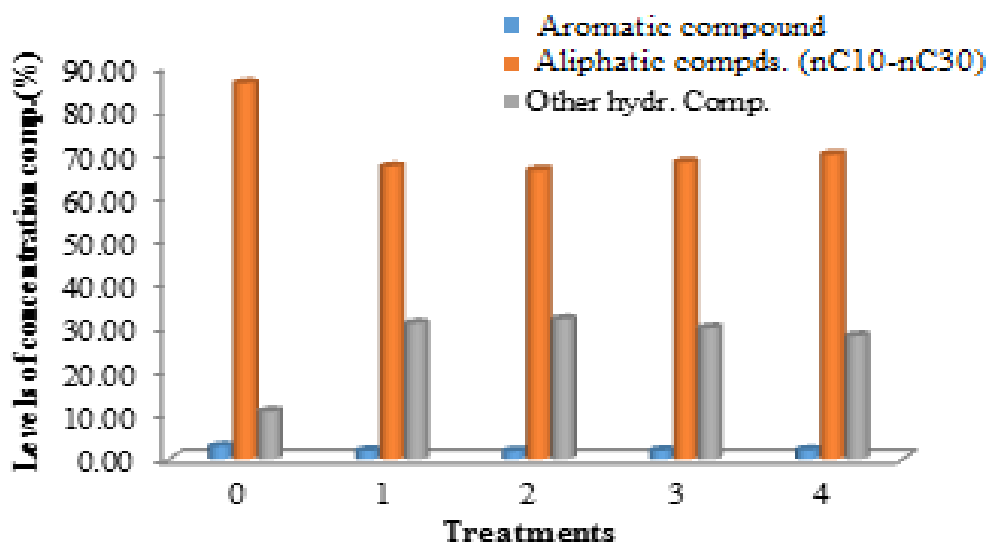

Figure 4. The relationship between treatment and levels of component hydrocarbons in sludge before and after contact 35 days with suspension BF strain PHCDB20

Figure 4 shows that treatment 2 is better than treatment 1,3 , and 4 in a decrease in the concentration of the normal alkane (nC10 - nC30) from $85.98 \%$ to $66.04 \%$, as well as aromatic components decreased from $3.03 \%$ to $1.90 \%$, and the concentration of the other hydrocarbon components have increased from $10.99 \%$ to $32.06 \%$ with the number of peaks seen increased from 11 to 24 .

Decreasing the concentration of the hydrocarbon component and increasing the number of peaks indicate some hydrocarbons are degraded. A decrease in the amount of hydrocarbon component concentrations also occur in treatment 1,3 , and 4 , but in a narrower range despite the increase number of other hydrocarbon components of the same peaks. It can be assumed that treatment 2 is better than treatment 1,3 and 4 in lowering concentrations of hydrocarbon components after contact during the 35 days between the suspension of the sludge BF strain PHCDB20 $0^{[16,25,26,27]}$.

Aliphatic components identified a homologous series of normal alkanes nC10 - nC30 consists of n-decane, n-undecane, n-dodecane, n-tridecane, n-tetradecane, npentadecane, n-hexadecane, n-heptadecane, n-octadecane, n-nonadecane, n-icosane, n-heneicosane, n-docosane, n-tricosane, n-tetracosane, n-pentacosane, n-hexacosane, n-heptacosane, n-octacosane, n-nonacosane, n-triacontane. ${ }^{[12,16,26,27]}$

Figure 5 shows the change in concentration of a normal components n-alkanes (C10, C15, C20, C25, C30) after contact for 35 days. 


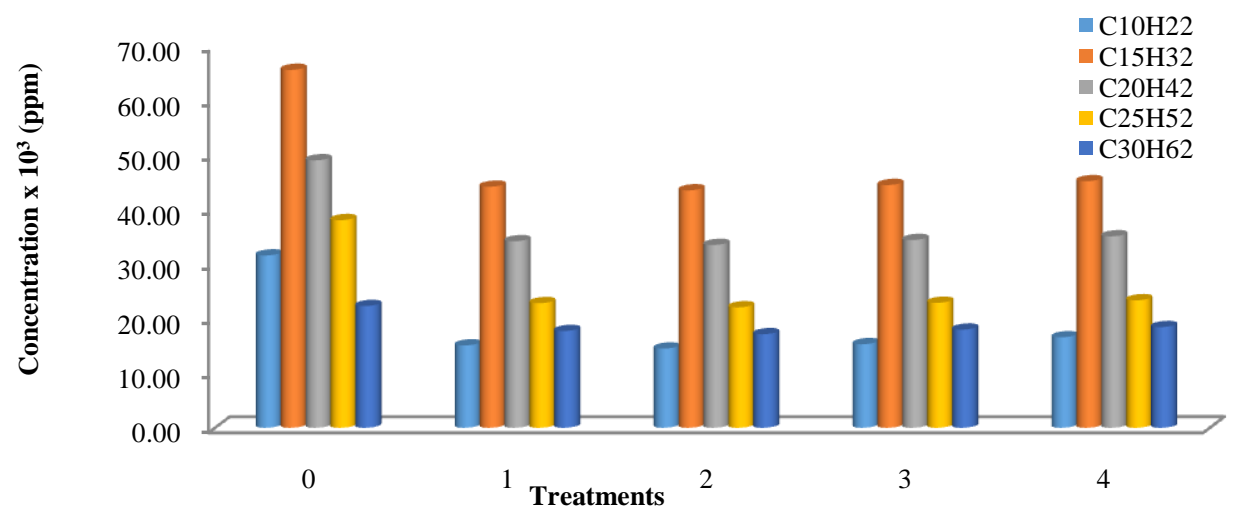

Figure 5. The relationship between treatment versus aliphatic hydrocarbons concentration after contact 35 days to suspension BF strain PHCDB20 with sludge.

Results of the data analysis GC-MS showed changes in the concentration of components aliphatic hydrocarbon based on treatment after contacting between BF strain PHCDB20 with sludge for 35 days. There are five components of normal alkanes representing 21 alkane components identified in the sludge. The highest concentrations decline was indicated in the treatment 2 , namely: $31.64 \times 10^{3} \mathrm{ppm}$ decane $\left(\mathrm{C}_{10} \mathrm{H}_{22}\right)$ became $14.54 \times 10^{3} \mathrm{ppm} ; 65.70 \times 10^{3} \mathrm{ppm}$ pentadecane $\left(\mathrm{C}_{15} \mathrm{H}_{32}\right)$ became $43.58 \times 10^{3} \mathrm{ppm} ; 49.10 \times 10^{3} \mathrm{ppm}$ icosane $\left(\mathrm{C}_{20} \mathrm{H}_{42}\right)$ became $33.56 \times 10^{3} \mathrm{ppm}$; $38.12 \times 10^{3} \mathrm{ppm}$ pentacosane $\left(\mathrm{C}_{25} \mathrm{H}_{52}\right)$ became $22.11 \times 10^{3} \mathrm{ppm}$; and $22.36 \times 10^{3} \mathrm{ppm}$ triacontane $\left(\mathrm{C}_{30} \mathrm{H}_{62}\right)$ to $17.18 \times 10^{3} \mathrm{ppm}$; whereas the same alkane components for treatment 1,3 , and 4 also decreased, but the amount of the decline range is narrower than treatment 2 , so it is stated that treatment 2 is better than other treatments in terms ofcompounds degraded. ${ }^{[12,25,26,27,28,29]}$

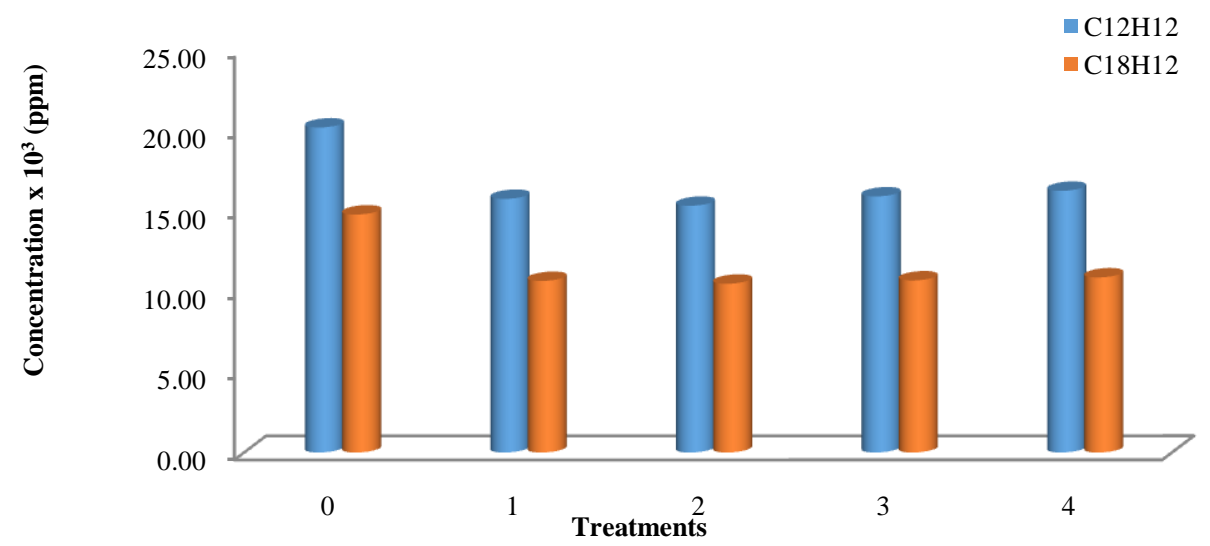

Figure 6. The relationship between treatment and aromatic hydrocarbons concentrationafter contact 35 days to suspension BF strain PHCDB20 with sludge. 
The GC-MS chromatograms of data is identified only two kinds of aromatic compounds, namely 2.7-dimethyl naphthalene $\left(\mathrm{C}_{12} \mathrm{H}_{12}\right)$ and azulene $\left(\mathrm{C}_{18} \mathrm{H}_{12}\right)$. After calculating the concentration of both the aromatic components and comparing before and after contact between a suspension of BF strain PHCDB20 and sludge for 35 days, shown in Figure 6. The results provide information that the decrease in the concentration of both aromatic compounds in the highest sludge for treatment 2 , respectively $20.18 \times 10^{3} \mathrm{ppm} \mathrm{C}_{12} \mathrm{H}_{12}$ became $15.32 \times 10^{3} \mathrm{ppm}$; while $14.77 \times 10^{3} \mathrm{ppm}$ $\mathrm{C}_{18} \mathrm{H}_{12}$ became $10.48 \times 10^{3} \mathrm{ppm}$. Treatment 1,3 and 4 experienced a decline in the concentration of aromatic components is less than the initial concentration, but the diminution in range that is narrower than the decrease in concentrations of the same components in treatment 2 . $^{[12,27,28,29]}$

Total decrease in the concentration of total hydrocarbon components against each component is calculated based on the highest decrease in peak areas shown by the treatment $2(39.71 \%)$, followed by treatment $1(38.13 \%)$, treatment $3(37.55 \%)$, and treatment $4(35.99 \%)$. This shows that treatment 2 isthe best in degrading hydrocarbon components in sludge than treatment 1,3 , and $4 .^{[16,27,28,29,30]}$

Biodegradation of petroleum sludge by BF strain PHCDB20, beginning with the mechanisms hydrocarbons contained in petroleum as the substrate is broken down in advance through oxidation processes involving oxygen as an electron acceptor. This oxygen plays a role in cellular metabolism as a reactant involves monooxygenases enzyme. These enzymes catalyze the entry of one atom into an organic compound. Oxygen is joined with the organic compounds in the form of hydroxyl $(\mathrm{OH})$ and one other oxygen atom to form a water molecule. ${ }^{[29,31,32,33,34]}$

Saturated aliphatic hydrocarbon degradation mechanisms by microorganisms is different to aromatic hydrocarbon degradation mechanisms. Aliphatic hydrocarbon degradation process involves oxidation of molecular $\left(\mathrm{O}_{2}\right)$ as a source of reactants and incorporation of one oxygen atominto oxidized hydrocarbons, while the aromatic hydrocarbon begins with ring degradation by entry of molecules $\mathrm{OH}^{-} \cdot{ }^{[5,33,34,35]}$

\section{Conclusion}

Results of this study prove that Bacillus Flexusstrain PHCDB20 Callyspongia sp sponge symbiont microbes acquired from extreme environments contaminated with petroleum waste Melawai Beach Balikpapan in East Kalimantan Indonesia can degrade petroleum sludge. Indicator of biodegradation between suspension of $\mathrm{BF}$ strain PHCDB20 and sludge observed for gas on contact time of day to 10, and odors on contact time to 15 days for treatment 2 and the same thing is true of treatment 1,3 and 4 is observed there is gas at the time of contact day 15 and odor on day 20. Other parameters of the biodegradation observed changes in $\mathrm{pH}$ of the suspension during the contact process and the increase in absorbance of the suspension showed an increase in the number of colonies and the size of bacterial cells. Based on the quantitative analysis of the level of biodegradation hydrocarbon componentstotal in sludge, treatment 2 isthe best, followed by treatment 1,3 and 4 . The same thing also shown the results of GC-MS analysis, which is a change in the concentration of all the components of the hydrocarbon in the sludge after contact for 35 days. Decrease the 
greatest concentration of hydrocarbon components shown in the second treatment followed by treatment 1, 3 and 4 . The results of the analysis of a decrease in the concentration of alkanes and aromatic components with the best performance was shown by treatment 2 , followed by treatment 1,3 , and 4 . These results were confirmed in the results of the chromatogram GC showed a decrease in the relative abundance of hydrocarbon components and a maximum of treatment 2 followed by treatment 1, 3 and 4. Aliphatic hydrocarbons components detected in the sludge were $\mathrm{nC} 10-\mathrm{nC} 30$ and aromatic components were 2.7-dimethyl naphthalene $\left(\mathrm{C}_{12} \mathrm{H}_{12}\right)$ and azulene $\left(\mathrm{C}_{18} \mathrm{H}_{12}\right)$.

\section{References}

[1] Vacelet, J., and Donadey, 1977,"Electronmicroscope study of the association between methane-oxidizing bacteria and deep sea carnivorous cladorhizid sponge,'J. Mar. Ecol. Prog. Ser., 145, 77-85

[2] Gan, S., Lau, E.V., and Ng,H.K., 2009, "Remediation of Soils Contaminated with Polycyclic Aromatic Hydrocarbons (PAHs),”J. Haz. Mat., 172, 532-549

[3] Udofia, E., 2008,"Rate of biodegradation of crude oil by microorganism isolate from oil sludge environment,"African J.Biotechnol., 7, 24

[4] Grihchenkov, V.G., Townsend, R.T., Mc Donald., T.J., Autenrieth,R. L., Bonner, J.S., and Boronin, A.M., 2000,"Degradation of petroleum hydrocarbons by facultative anaerobic bacteria under aerobic and anaerobic conditions,"J. Proc.Biochem., 35, 889-896

[5] Syakti, D. A., Yani, M., Hidayati, VN., Siregar, S.A. Doumeng, P., andSudiana, I. M., 2013, "The Bioremediation potential of hydrocarbonoclastic bacteria isolated from a Mangrove Contaminated by Petroleum Hydrocarbons on the Cilacap Coast, Indonesia,'J.Bioremed., 17(1), 11-20

[6] Cai, Quan-Ying, Mo, C., Wu, Q.,Zeng, Q., Katsoyiannis, A., and F'erard,J., 2007,"Bioremediation of polycyclic aromatic hydrocarbons (PAHs)contaminated sewage sludge by different composting processes,"J. Haz. Mat., $142,535-542$

[7] Alamri, A. S., 2012,"Biodegradation of microcystin-RR by Bacillus Flexus isolated from a Saudi freshwater lake,"Saudi J. Biol. Sci.; 19(4), 435-440

[8] Rivas, F., and Javier, 2006, "Polyciclic aromatic hydrocarbons sorbed on soils: A short review of chemical oxidation based treatments,"J. Haz. Mat., 138, 234-251

[9] Wu, Y., Teng, Y., Li, Z., Liao, X., and Luo, Y., 2008, "Potential role of polycyclic aromatic hydrocarbons (PAHs) oxidation by fungal laccase in the remediation of an aged contaminated soil,'J. Soil Biol. Biochem., 40, 789-796

[10] Teng, Ying, Luo, Y., Sun, M., Liu, Z.,Li, Z., and Christie, P., 2010, "Effect of bioaugmentation by paracoccus sp. strain HPD-2 on the soil microbial community and removal of polycyclic aromatic hydrocarbons from an aged contaminated soil,’J. Biores. Technol.,101, 3437-3443 
[11] Yani, M. and Akbar, Y., 2012, "Diesel oil biodegradation process by mixed culture of hydrocarbon degrader bacteria,"J. Agricult. Indust. Technol., 19(1), 40-44

[12] Okoro, C., andChuma, 2010, "Application of seawater microbial inocula for the remediation of hydrocarbon polluted mangrove swamp in the Nigerian oil rich Niger Delta,'J. Nat. Sci., 8(8), 152-162

[13] Zocchi, E.G., Basile, C., Cerrano, G., Bavestello, M., Giovale, S.,Bruzzone, L., Guida, A., Carpaneto, Magrassi, R., and Usai, C., 2002,“ABA-and cADPR-mediated effects on respiration and filtration downstream of the temperature-signaling cascade in sponges,'J. Cell Sci., 116, 629-636

[14] Thakur, N. L., and Muller, W., 2004, "Biotechnological Potensial of Marine Sponges,'J. Curr. Sci.,11, 86

[15] Ismet, S.M., Soedharma, D., and Effendi, H., 2011, "Morphology and cell biomass of sponge Aaptosaaptos and Petrosiasp,'J.Tropic. Mar.Sci. Technol., 3 (2), 153-161

[16] Akinde, B. S., Iwuozor, C. C., and Obire, O., 2012,“Alkane Degradative Potentials of Bacteria Isolated From the Deep Atlantic Ocean of the Gulf of Guinea,"J.Bioremed. Biodegrad., 3(1), 1- 6

[17] Marzuki, I., Noor, A., Djide, N.M., and La Nafie, N., 2014,"Isolation and Identification on Degradator Bacterial of Petroleum waste which Symbionts with Sponge Callyspongiasp from Melawai Beach," ProceedingInternationalConfrence on the Sciences (ICOS), MakassarIndonesia, 1, 493-503

[18] Marzuki, I., Noor, A., Djide, N.M., and La Nafie, N., 2015, "Molecular characterization of gene 16S rRNA micro symbionts in sponge at Melawai Beach, East Kalimantan,'J. Mar. Chim. Acta, 16(1), 38-46

[19] Xu, L., Cao, Y., Xiang-Tian, Deng,D., Xu, L. N., and Liu, Z. Y.,2012,"Molecular detection of tas A qene in endophytic bacillus species and characterization of the gene in Bacillus amyloliquefaciens,"African $J$. Biotechnol., 11(23), 6212-6219

[20] Silberhorn, Thiell, A.M.,V., and Imhoff, J.F., 2007,"Abundance and bioactivity of cultured sponge associated bacteria from the Mediterranean Sea,"J. Microbial Ecol., 55, 94-106

[21] Seo, J.S., Keum, Y.S., and Li., Q.X., 2009, "Bacterial degradation of aromatic compounds,'Int.J.Environ.Res.Public Health, 6, 278-309

[22] Ferrarese, Elisa, Andreottola, G., and Oprea, I. A., 2008,"Remediation of PAH-contaminated sediments by chemical oxidation,"J. Haz. Mat., 152, 128139

[23] Tam, N.F.Y and Wong, Y.S., 2008, "Effectiveness of bacterial inoculum and mangrove plants on remediation of sediment contaminated with polycyclic aromatic hydrocarbons,"Mar. Poll. Bull., 57, 716-728

[24] Avecedo, Francisca, Lecticia, Pizzul, Maria, Castilloc, P., Raphael, Cuevas, Maria, and Diez, C., 2011, "Degradation of Polyciclic aromatic hydrocarbons by the Chilean white-rot fungus Anthracophyllum discolor,'J. Haz. Mat., 185, 212-219 
[25] Cerqueira, V. S., Hollenbach, E. B., Maboni, F., Vainstein, M. H., Camargo, F. A. O., Peralba, M. C.R., and Bento, F. M., 2011, “ Biodegradation potential of oily sludge by pure and mixed bacterial cultures,"Bioresour. Technol.,102,11003-11010

[26] Lin, Y., andCai, L. X., 2008,"PAH-degrading microbial consortium and its pyrene-degrading plasmids from mangrove sediment samples in Huian," ChinaMar. Poll. Bull.,57, 703-706

[27] Noor, A., Mille, G., Liong.S., andJawahir,B.,1987,"N-alkane distribution in coastal surficial sediments from Ujungpandang, Indonesia,"Mar. Poll. Bull., 18(9), 505-507

[28] Tapilatu, Y., Acquaviva, M., Guigue, C., Miralles, G., and Bertrand, J. C., 2010, "Isolation of alkane-degrading bacteria from deep-sea Mediterranean sediments,"Letters in Appl.Microbiol., 50, 234-236

[29] La Nafie, N., 2007,“Application of Fenton's reagent on remediation of Polycyclic Aromatic Hydrocarbons (PAHs) in spiked soil,'Indo. J. Chem., 7(2), 208-213

[30] Kim, T.K., Hewavitharana, A.K., Shaw, P.N., and Fuerst, J.A., 2006,"Discovery of a new source of rifamycinantibiotics in marine sponge actinobacteria by phylogenetic prediction,"J.Appl. Environ. Microbiol.,72, 2118-2125

[31] White, R. J., Patel, J., Ottesen, A., Arce, G., Blackwelder, P., Lopez, V. J., 2012,"Pyrosequencing of Bacterial Symbionts within Axinellacorrugata Sponges: Diversity and Seasonal Variability," www.plosone.org, e38204,Journal PLoS ONE, 7(6), 1-12

[32] Ojo, O. A., 2006,"Petroleum-hydrocarbon utilization by native bacterial population from a wastewater canal Southwest Nigeria,"African J. Biotechnol.,5, 333-337

[33] Piedad, D. M., Grigson, S.J., Peppiatt C. J, Burgess J. G.,2000,“Isolation and characterization of novel hydrocarbon-degrading euryhaline consortia from crude oil and mangrove sediments,"J. Mar.Biotechnol (NY), 2, 522-532

[34] Liu, Z., Shao, Z., 2007, "The diversity of alkane degrading bacteria in the enrichments with deep sea sediment of the South China Sea,"J.Wei Sheng Wu XueBao., 47, 869-873

[35] Wilkinson, C.R., 1978,"Microbial Association in sponges II: Numerical analysis of sponges and water bacterial population", Mar.Biol.Journal, 49 (2), 69-176. 
